\title{
Desain balok beton menggunakan penulangan lembaran continue fiber reinforced polymer (FRP)
}

\author{
Fikri Alamia,* \\ a Jurusan Teknik Sipil, Universitas Lampung, Jl. Soemantri Brojonegoro No. 1 Bandar Lampung, 35145, Indonesia
}

\section{H I G H L I G H T S}

- Penelitian terhadap penggunaan lembaran FRP sebagai kombinasi penulangan lentur dan geser telah dilakukan.

- Aggregate coating memberikan kontribusi yang signifikan terhadap sistem lekatan.

- Sistem penulangan menerus FRP dapat menjaga balok dari runtuh.

\section{N F O ART I K E L}

\section{Riwayat artikel:}

Diterima 12 Nopember 2019

Diterima setelah diperbaiki 24 Februari 2020

Diterima untuk diterbitkan 27 Februari 2020

Tersedia secara online 12 Maret 2020

\section{Kata kunci:}

Desain,

Balok beton,

FRP sheet.

\begin{abstract}
A B S T R A K
Fiber Reinforced Polymer (FRP) sudah banyak dipergunakan untuk perkuatan konstruksi beton bertulang maupun untuk penulangan internal beton. Namun penggunaan FRP sebagai penulangan internal pada struktur beton, masih didominasi dengan penggunakan tulangan Bar (FRP Bars). Sementara penggunaan FRP tipe lembaran (FRP Sheet) masih terbatas dikarenakan kesulitan dalam pemahaman metode desain dan juga permasalahan debonding antara lembaran FRP dan beton. Tulisan ini membahas cara mendesain balok beton dengan menggunakan penulangan lembaran FRP, baik berupa lembaran FRP tipe pelat, maupun lembaran FRP yang kontinyu yang dapat dipergunakan sebagai kombinasi penulangan lentur dan geser. Hasil penelitian yang sudah diseleksi juga ditampilkan dalam tulisan ini sebagai perbandingan dengan teori yang dikembangkan.
\end{abstract}

Diterbitkan oleh Jurusan Teknik Sipil Universitas Lampung

\section{Pendahuluan}

FRP adalah material komposit yang terbuat dari material polimer yang diperkuat dengan serat-serat seperti, carbon, aramid, glass dan basalt. Kekuatan dan kekakuan utamanya diperoleh dari serat dan perekat yang mengikat serat-serat untuk membentuk komponen struktur dan nonstruktur. FRP mempunyai sifat yang menguntungkan diantaranya adalah merupakan material yang tidak berkorosi sehingga berpotensi menggantikan tulangan baja, mempunyai kuat tarik yang tinggi dan juga ringan. Namun FRP juga mempunyai kekurangan diantaranya adalah sifatnya yang getas sehingga perlu desain khusus untuk memperlakukan material ini jika dipergunakan sebagai tulangan internal utama dalam struktur beton.

\footnotetext{
* Penulis koresponden.

Alamat e-mail: fikri.alami@eng.unila.ac.id (F. Alami). Peer review dibawah tanggung-jawab Jurusan Teknik Sipil Universitas Lampung.

https://doi.org/10.23960/rekrjits.v24i1.6
}

\section{Metode Penelitian}

\subsection{FRP untuk perkuatan eksternal struktur}

Perkuatan struktur merupakan suatu usaha untuk meningkatkan masa layan atau fungsi dari bangunan $[1,2]$. Perkuatan struktur dilakukan untuk menanggulangi kerusakan pada elemen struktur, perubahan fungsi bangunan dan kesalahan pada waktu melakukan perencanaan ataupun pelaksanaan. Gambar 1 menunjukkan pada elemen balok beton bertulang dan pelat dimana selimut beton telah hancur dan tulangan lentur ter-ekspose terhadap lingkungan. Dengan ter-ekspose-nya tulangan maka korosi akan cepat terjadi dan struktur akan mengalami penurunan kinerja jika terus dibebani. Sedangkan Gambar 2 menunjukan aplikasi penggunaan CFRP sebagai penulangan eksternal pada balok dan dinding batu bata. Penggunanan serat kontinus dua arah (biaxial fiber sheet) pada balok dapat diaplikasikan sebagai tulangan lentur sekaligus tulangan tarik. Pada Gambar 2 lembaran FRP dengan arah serat utama searah tinggi dinding dipasang sebagai penulangan lentur eksternal untuk meningkatkan kapasitas momen lenturnya. 

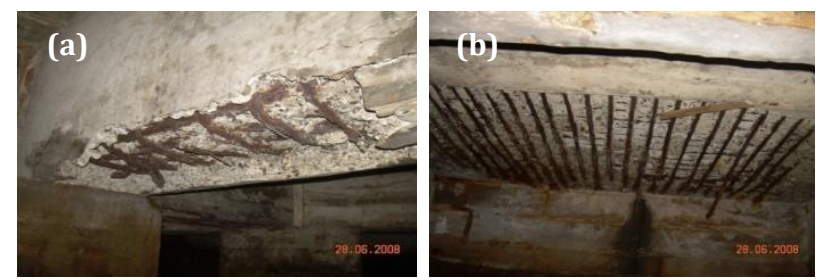

Gambar 1 Contoh kerusakan pada elemen struktur beton:

(a) balok, dan (b) pelat

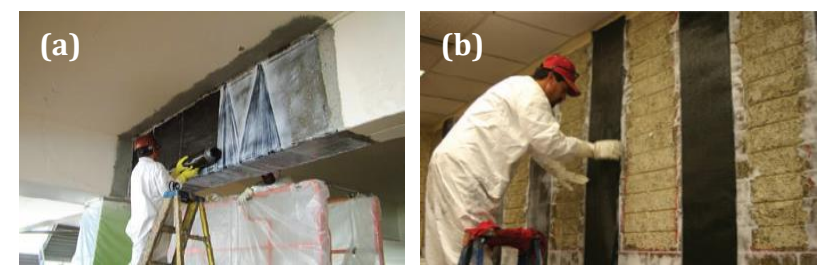

Gambar 2 (a) Perkuatan geser balok beton bertulangan dengan FRP wrap dan (b) perkuatan dinding batu bata dengan menggunakan FRP tipe wrap.

\subsection{FRP sebagai penulangan internal struktur}

FRPs sukses digunakan dalam aplikasi-aplikasi teknik sipil lebih dari tiga dekade [3]. Namun aplikasi pertama yang diketahui FRP sebagai penulangan internal dalam struktur beton dilaporkan pada tahun 1996. Ini karena FRPs adalah sebuah solusi yang efisien dan terjangkau dalam menggantikan tulangan baja dalam struktur beton karena ketahanan terhadap karat, berat yang ringan, tahan lama dan punya kekuatan tinggi. Aplikasi FRP sebagai tulangan internal dalam bentuk bar dapat dilihat pada Gambar 3 yaitu sebagai penulangan lantai jembatan. Sedangkan pada Gambar 4 lembaran FRP dipergunakan pada elemen-elemen panel, kolom, dan balok beton bertulang baik sebagai bekisting sekaligus penulangan luar. Lembaran serat (dry fabric) sebelum dicuring dengan resin yang berprospek pada pembentukan sistem 2D/3D penulangan baru, memungkinkan penggunaan material secara efektif dan efisien. Meskipun FRP fabric potensial, sedikit penelitian pada penggunaan tulangan ini secara internal dilaporkan dalam beberapa literatur.

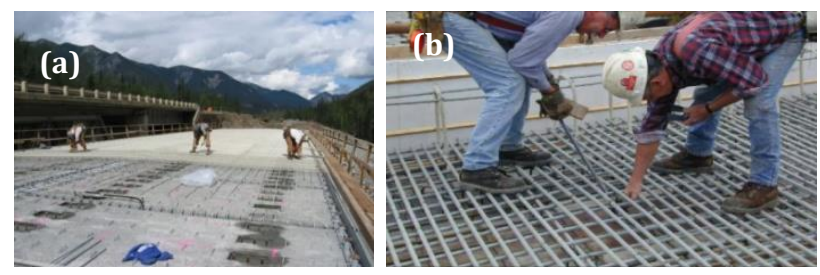

Gambar 3 (a) Penerapan FRP reinforcing bars pada lantai jembatan Salmon River Bridge, British Columbia; dan (b) pemakaian GFRP dan CFRP reinforcement pada lantai Wotton Bridge.

\subsection{Konsep desain FRP sebagai penulangan internal}

Metode utama kompatibilitas tegangan-regangan dan keseimbangan gaya dapat digunakan untuk mendesain balok beton dengan tulangan FRP dengan berbagai macam bentuk. Kurva klasik Hognestad [4] yang ditampilkan pada Gambar 5, digunakan untuk memodelkan hubungan tegangan dan regangan beton dalam tekan. Didalam mendesain balok, dua mode kegagalan balok dapat dicapai, salah satunya melalui beton hancur pada daerah tekan, atau tulangan FRP patah pada daerah tarik.

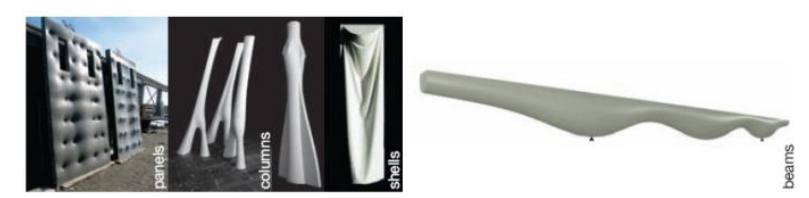

Gambar 4 Bentuk struktur beton menggunakan fibre fabrics (Orr dkk, 2010).

Gambar 6 merupakan contoh penampang balok beton dengan tulangan internal FRP menerus (kombinasi tulangan lentur dan geser) dan diagram tegangan dan regangan di sebelahnya. Beberapa asumsi diambil dalam menganalisis dan mendesain kapasitas beban dan momen pada penampang ini:

- Tulangan melengkung pada sisi bawah diabaikan dalam perhitungan.

- Kegagalan diasumsikan beton hancur terlebih dahulu.

- Pada kondisi balok belum retak, kontribusi tegangan Tarik beton diperhitungkan.

- Modulus of elasticity yang digunakan pada tulangan FRP dianggap sama.

- Tulangan FRP vertikal diperhitungkan dalam analisis dan desain.

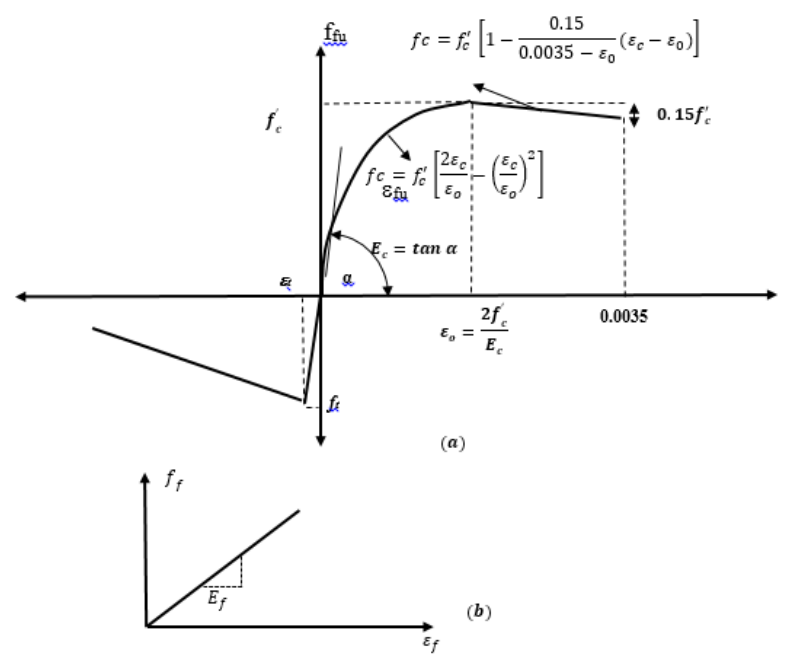

Gambar 5 (a) Idealisasi kurva tegangan-regangan untuk beton pada uniaxial-compression (Park \& Paulay, 1975)); (b) Kurva tegangan-regangan pada FRP.

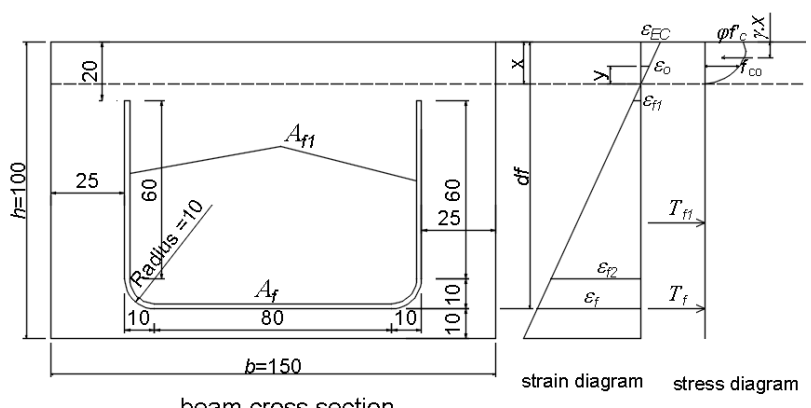

Gambar 6 Penampang balok, parameter balok, diagram regangan dan tegangan FRP 
Jarak garis netral dari serat tekan atas $(x)$ diperoleh dari keseimbangan gaya internal pada balok. Total gaya tekan adalah sama dengan total gaya tarik,

$$
\begin{gathered}
C_{c}=T_{f}+T_{f 1} \\
\alpha f_{c}^{\prime} b x=f_{f} A_{f}+f_{f} A_{f 1}
\end{gathered}
$$

Dengan parameter yang diketahui, momen tahanan internal $(M)$ diperoleh dengan mengambil jumlah dari momen-momen terhadap tengah penampang:

$$
M=\alpha f_{c}^{\prime} b x\left[\frac{h}{2}-\gamma x\right]+f_{f} A_{f}\left[d_{f}-\frac{h}{2}\right]+f_{f 1} A_{f 1}\left[\frac{h}{2}-\frac{h f}{2}\right]
$$

Sebuah pengujian lentur dilakukan pada suatu balok yang ditulangi didalamnya dengan tulangan berbentuk FRP box di atasnya terdapat lubang-lubang terbuka pada jarak tertentu seperti yang dapat dilihat pada Gambar 9. Untuk menjamin tidak terjadi debonding maupun slip antara beton dan tulangan FRP, maka terlebih dahulu FRP box dikasari permukaannya dengan menggunakan agregat coating dengan ukuran maksimum $2 \mathrm{~mm}$ yang di lekatkan ke seluruh permukaan FRP Box dengan epoxy resin sampai mengeras seperti yang ditunjukkan pada Gambar 7 dan Gambar 8.

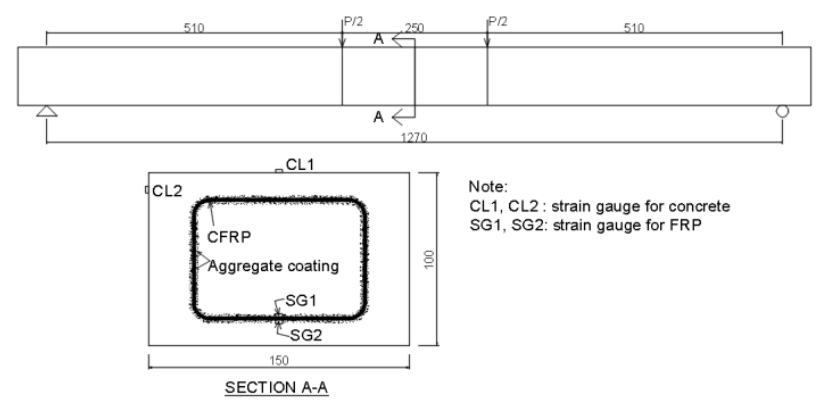

Gambar 7 Penampang CFRP yang dikasari dengan aggregate coating.

Empat buah strain gauge dipergunakan pada balok ini yang diletakkan di tengah bentang untuk memonitoring regangan yang terjadi saat balok di uji. Satu strain gauge diletakkan pada permukaan balok sebelah atas dan satu lagi di sisi kiri balok sejarak $10 \mathrm{~mm}$ dari permukaan atas balok. Sedangkan 2 strain gauge lainnya diletakkan pada tulangan FRP box di sisi dalam dan luar box untuk memonitoring regangan yang terjadi pada serat FRP.

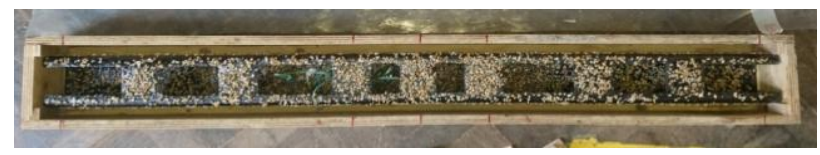

Gambar 8 Menunjukkan penampang CFRP

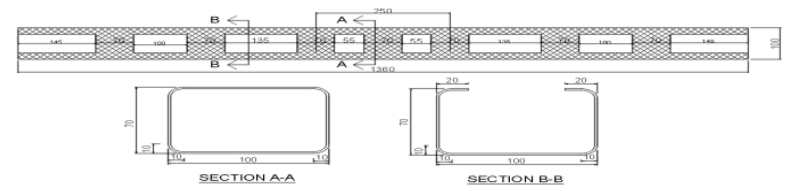

Gambar 9 Tambah atas tulangan lembaran FRP dan penampangpenampang.
Setelah balok beton berumur 28 hari, dilakukan pengujian lentur dimana balok diletakkan pada dua tumpuan sederhana sendi-rol dan dibebani dengan sistem dua beban titik (Gambar 10). Jarak kedua beban titik adalah sebesar $250 \mathrm{~mm}$ yang berfungsi sebagai daerah momen konstan pada balok. Lima dial gauge diletakkan pada balok, namun hanya dial gauge yang di tengah digunakan untuk memplotkan hubungan antara beban dan defleksi tengah bentang balok

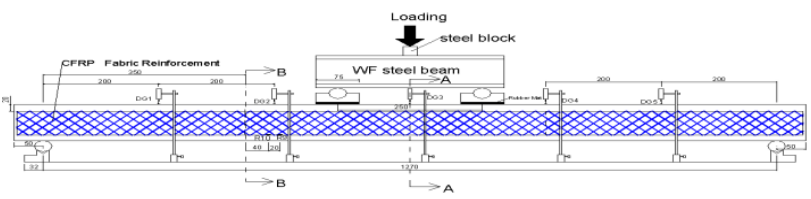

Gambar 10 Testing set-up untuk CFRP RC beam

\section{Hasil dan Pembahasan}

Gambar 11 menunjukkan hubungan antara defleksi tengah bentang balok dan beban. Ada empat buah grafik yang diplotkan secara bersama pada gambar tersebut untuk dibandingkan satu dengan yang lain. Hasil eksperimen menunjukkan bahwa balok dapat menahan beban maksimum sebesar $14,110 \mathrm{kN}$ dan kemudian turun ke beban 10,642 kN dan terus mampu menahan beban konstan sampai defleksi mencapai $36,865 \mathrm{~mm}$ sebelum akhirnya balok gagal dan di unloading sampai defleksi mencapai $15,43 \mathrm{~mm}$. Balok gagal akibat beton hancur pada regangan 0,002848 seperti yang ditunjukkan pada Gambar 12.

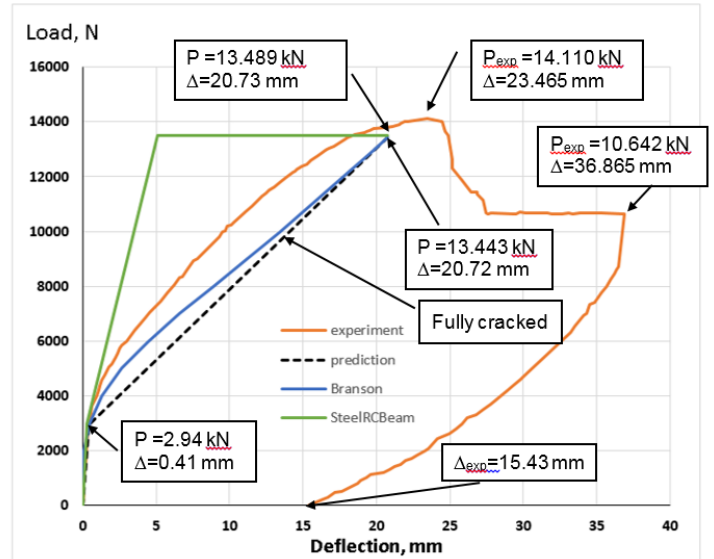

Gambar 11 Beban vs defleksi tengah bentang pada balok CFRP

Hasil eksperimen ini dibandingkan secara teoritis. Jika desain ini disetarakan dengan balok beton bertulang biasa yang diperkuat dengan dua buah tulangan diameter $10 \mathrm{~mm}$, maka akan memberikan beban maksimum sebesar 13,489 $\mathrm{kN}$ dengan lendutan maksimum sebesar 20,73 mm. Jika dibandingkan secara teori dengan menggunakan dua pendekatan, pendekatan pertama balok dianggap full cracked, ternyata balok mampu menahan beban maksimum sebesar 13,443 kN dengan defleksi sebesar 20,72 mm. Pendekatan kedua adalah dengan menggunakan momen inersia efektif atau yang dikenal sebagai Branson theory, ternyata balok mampu menahan beban yang sama seperti pendekatan pertama. 
Gambar 13 (atas) dan (bawah) menunjukkan distribusi retak pada balok CFRP dibawah beban lentur. Retak vertikal terdistribusi sepanjang balok, pada "constant moment zone" (between point loads), retak vertikal ini terus merambat ke arah atas balok. Retak memanjang nampak menghubungkan retak-retak vertikal selama beban meningkat.

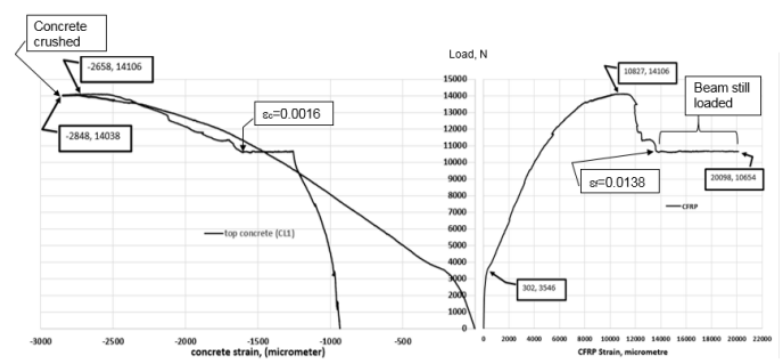

Gambar 12 Beban vs regangan pada balok CFRP di tengah bentang
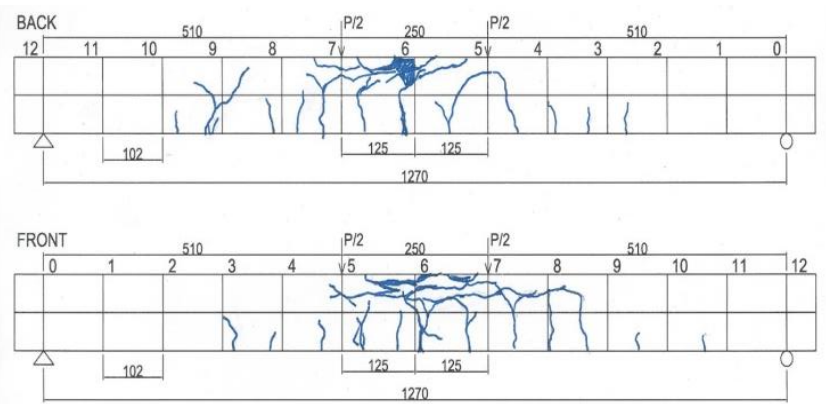

Gambar 13 Sketsa pola retak pada balok CFRP bagian depan dan belakang

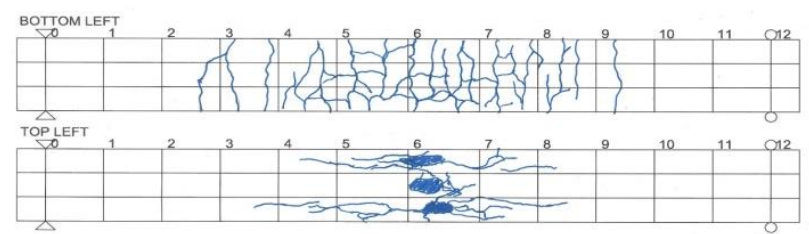

Gambar 14 Sketsa pola retak pada balok CFRP bagian bawah dan atas

Retak-retak pada bagian bawah penulangan balok CFRP pada Gambar 14 atas menunjukkan retak menyebar melalui penulangan FRP dan menghilangkan retak lokal. Retakretak juga terjadi pada bagian atas balok CFRP. Retak terbuka terjadi pada bagian tengah balok. Retak-retak mulai pada lokasi horizontal dan mengalir secara horizontal menuju titik pembebanan, yaitu $125 \mathrm{~mm}$ kiri dan kanan dari balok (Gambar 14 bawah). Sedangkan Gambar 15 menunjukkan bagian bawah balok setelah dibongkar/ dikupas betonnya dimana ada lekatan yang baik antara beton dan tulangan CFRP. Beton masih lengket di antara "aggregate coatings" setelah dikupas.

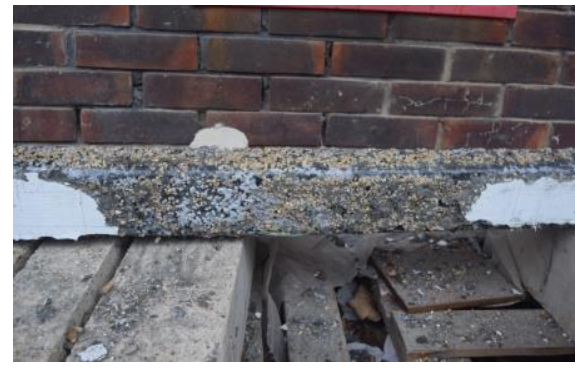

Gambar 15 Sisi bawah balok setelah dibongkar

\section{Simpulan}

- Beban ultimate 4,96 \% lebih besar dari pada prediksi teori. Perhitungan ini berdasarkan pada regangan tekan beton 0.0028 dan sama dengan asumsi teori.

- Beton gagal pada regangan 0.0028, sementara teori seharusnya 0.0035. Ini disebabkan karena beton retak dan terbelah searah lebar balok. Ini diperkirakan karena garis netral yang terlalu tinggi dalam desain. Keseimbangan antara gaya tekan dan gaya tarik ketika mendekati keadaan ultimate tidak dapat bertahan lebih lama dikarenakan area tekan yang kecil. Ketika retak vertikal pada sisi depan dan belakang balok terkoneksi melintasi lebar balok dan gaya tekan meningkat dan beton terbelah terjadi pada bagian atas balok di bawah regangan ultimate beton yaitu 0.0035 .

- Secara experimental balok berdefleksi sebesar 23.465 $\mathrm{mm}$. lebih tinggi dari teori yaitu $20.72 \mathrm{~mm}$. Perbedaan sebesar $13,24 \%$.

- Aggregate coating memberikan kontribusi yang signifikan terhadap system lekatan untuk balok ini sehingga balok tidak gagal akibat debonding.

- Single biaxial $\pm 45^{\circ}$ CFRP reinforcement system untuk balok menunjukkan perilaku daktail. Walaupun balok gagal akibat beton pecah pertama kali, balok tidak runtuh. Sistem penulangan menerus FRP ini dapat menjaga balok dari runtuh.

\section{Daftar Pustaka}

[1] Alami, F., Widyawati, R.: Studi eksperimental perkuatan geser balok beton bertulang dengan GFRP. Jurnal Rekayasa Teknik Sipil Universitas Lampung. 2011

[2] Alami, F.: Perkuatan lentur balok beton bertulang dengan glass giber reinforced polymer (GFRP). Proceeding HAKI pada Seminar dan Pameran HAKI 2010, di Hotel Borobudur Flores Ballroom Jakarta Pusat, 3-4 Agusutus 2010

[3] Zoghi, M.: The international handbook of FRP composites in civil engineering. Taylor \& Francis Group, 2014

[4] Park, R., Paulay, T.: Reinforced Concrete Structures, Singapore, 1975 